\title{
An Analysis on Comparison of the Static Load Test Performed to Post-Grouted Pile Foundation with Chinese, American and European Standard
}

\author{
Xianbin HUANG, Yujiao MEI, Yahong WANGREN, Tangyong LI, Bo LEI, Wei ZHAO
}

\begin{abstract}
In the paper, a study is conducted to pile foundation post-grouting and static load test, in which the tested value is used to compare with the standard of China, America and Europe. Taking Li-yuTuo bridge as study object, the trial piles - 3c2 and 3c4 with length of 33 meters and diameter of 1.2 meter are selected. The vertical bearing capacity of single pile is designed as $33000 \mathrm{kN}$ which thereafter is enhanced using post-grouting. The on-site static load test is employed to evaluate the bearing capacity of pile foundation that is obtained being $39220 \mathrm{kN}$ through self-balanced test. It is indicated through standard comparison that the bearing capacity calculated by China and America standard is akin to each other, turning to be excessively conservative and much less than the theoretical value of Europe. The Chinese standard shows bearing capacity after grouting is increased by 78.8 percent compared with pile foundation being not grouted. The post-grouting trial value is increased by 18.8 percent more than design value, 81.4 percent than theoretical value of general pile and 1.44 percent than theoretical value of post-grouting.
\end{abstract}

Keywords: bored pile; foundation; post-grouting; static load test; self-balanced test; vertical bearing capacity

\section{INTRODUCTION}

Located in a high seismic intensity area, Li-yuTuo covered bridge is a crowded public sightseeing complex integrating building and bridge. Dujiangyan proper is to the east. Qingcheng bridge and place of interest in lower reaches of Minjiang river are to the south. Huangiia Hexin leisure recreation resort is to the west. To the north are Dujiangyan Scenic Area and upper reaches of Minjiang river. It is situated at the upper reaches, 1200 meters away from Qingcheng bridge, G213 national highway, Dujiangyan proper.

The bridge is 579.5 meters long in total, with main bridge length 391.5 meters and approach bridge 188 meters. The main bridge span, whose length is 13 by $30 \mathrm{~m}$, is designed in the form of rigid frame bridge made up of three pieces of pre-stress section steel concrete piers. And the approach bridge uses T-beam bridge made up of one piece of pre-stress concrete characterized by pre-simple support and post-consecutive structure, whose span length is $6 \times 30$ meters $[1,2]$. See Fig. 1 for design sketch of $\mathrm{Li}$ yuTuo bridge. Li-yuTuo bridge is fraught with innovations and features ranging from pile foundation, pier, upper structure, design to test.

The paper mainly discusses the distinctive pile foundation. The bridge deck is designed as 15 meters in width and is fitted with two-way driving lane. The foundation adopts pile group foundation, where under each pier is equipped with a pile cap. There are four pile group foundations under pile cap, of which each pile has a diameter of 1.2 meter and a length of 33 meters. The designed vertical bearing capacity of single pile is 33000 $\mathrm{kN}$, belonging to a typical pile foundation of large load and small pile diameter. The post-grouting is designed to increase pile bearing capacity which is tested through static load test.

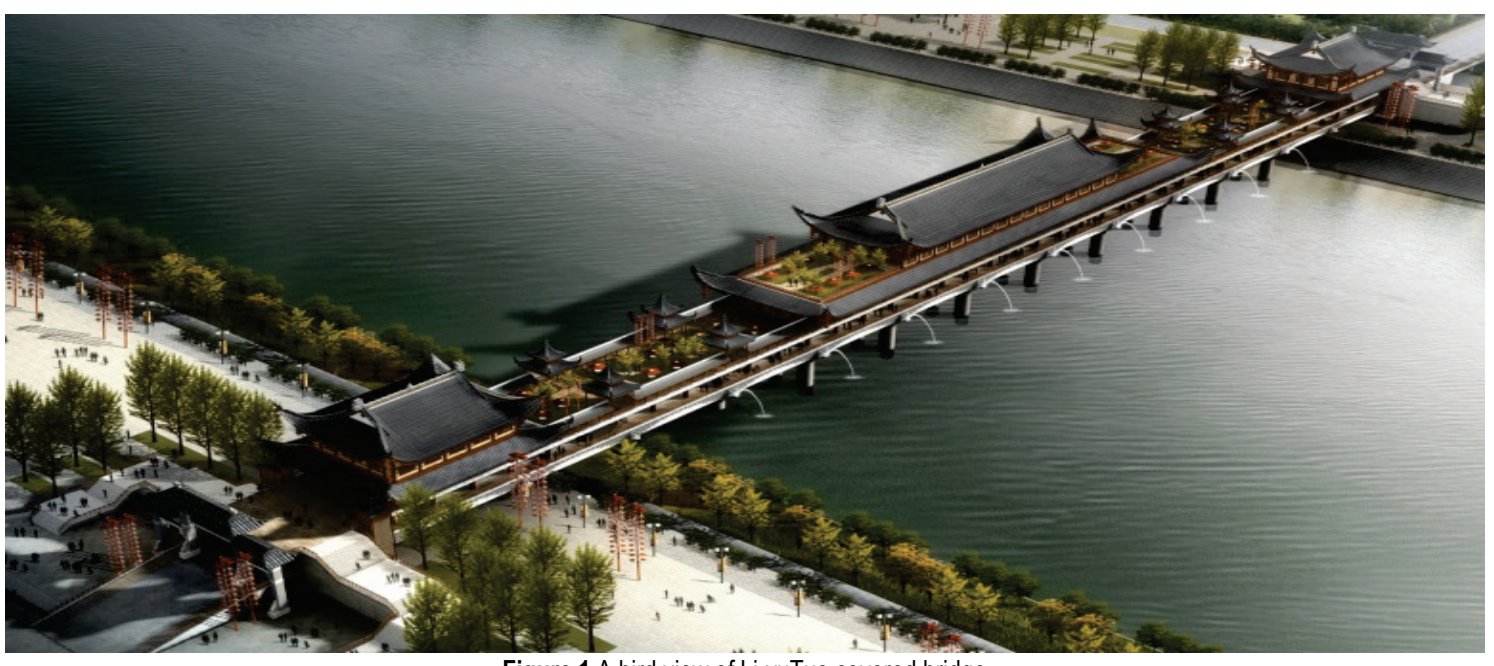

Figure $1 \mathrm{~A}$ bird view of Li-yuTuo covered bridge

The bored pile, recognized as one of safe, reliable and effective foundations, accounts for over 80 percent of material used in road and bridge construction [3]. The pile post-grouting is generated by pouring cement grout into pile base and pile side after pile foundation concrete satisfies provided strength. The cement grout serves the purpose of consolidating the loose soil at pile base and pile side, so as to increase bearing capacity of friction pile $[4,5]$. The contrast test performed by Cheng, Y. [6] shows that the pile tip post-grouting may not only effectively boost the pile-tip 
bearing capacity of super-long-diameter bored pile but partly enhance side friction resistance above the section of pile base, thus increasing whole pile bearing capacity. The pile tip post-grouting not only can enhance pile bearing capacity but effectively promote its strength, which is conducive to controlling foundation sedimentation. Wan, Z. H. [7] analyzes the change of load transfer function for postgrouting bored pile. Bauer, J. [8] discusses a method of analysing head displacements of piles subjected to lateral load test that is suitable for reliability calculation. Zhou, R. X. [9] conducts test research on bearing capacity characteristics of post-grouting piles for Taiping bridge, during which the ultimate bearing capacity, pile lateral resistance and pile tip resistance to have significant increase after grouting pile. Huang, T. [10] conducted research on base grouting effects of piles in Suramadu strait area of Indonesia. Because of poor penetration ability of soil in this area, not only the tip resistances are improved after grouting, but lateral frictional resistances are improved as well. The Dapp, S. and Dan, B. [11] carry out a test designed to compare the bearing capacity before and after pile tip postgrouting for the large-diameter pile foundation of Audubon bridge, demonstrating that the pile tip and pile lateral grouting have effectively improved bearing capacity of precast pile. Lai, P. [12] carried out a research on grouting technology of precast pile using indoor model test. The result shows that grouting pile tip and pile side can effectively increase bearing capacity of precast pile. Su, S. F. [13] has performed a study on the change of soft clay strength after grouting. Mullins, G. [14] has implemented a study on the application of tip post-grouting technology in non-cohesive soil, where the key factors that sway grouting effect have been specifically discussed. As such, Ruiz, M. E. [15] has proposed a numerical computation method to obtain sedimentation for load transfer theory of pile tip grouting.

For the relatively large vertical bearing capacity of pile foundation, test-based bearing capacity evaluation is a process which design and construction workers pay special attention to, as it costs lots of time, labour and money. It is well recognized at home and abroad that the traditional single-pile static load test provided by pile-loading or anchor pile with counterforce is the most reliable method to determine the bearing capacity of single pile [16]. Considering the pile-loading base area of $8 \times 8 \mathrm{~m}$ for concrete block (volume weight $2.4 \mathrm{t} / \mathrm{m}^{3}$ ), the upper area adopts pyramid shape featuring gradually decreased area. If the pile-loading test is applied to the project, the pile-loading height of concrete block would exceed 35 meters. Based on counterforce offered by anchor pile, it is estimated to require 16 anchor piles and it is needed to calculate anchor pile depth of reinforced concrete. Meanwhile above anchor pile should be equipped with the longitudinal \& cross beam that can bear over $33000 \mathrm{kN}$. It is thus clear that providing counterforce of over $33000 \mathrm{kN}$ is not easy regardless of pile-loading or anchor pile method used, which is rather costly and timeconsuming. With vertical bearing capacity of pile foundation being continuously improved in recent years, the selfbalanced test and static load test have attracted much attention from engineering industry. Since 1990s, Shi, P. D. $[17,18]$ and Gong, W. M. [19-22] have introduced selfbalanced test to China, and carried out numerous selfbalanced tests for various pile foundations. The essence of self-balanced test is the pre-embedded jack in the middle and bottom of pile. The jack is embedded in the force balance point with equation being: upper pile friction resistance equals lower pile tip resistance plus lower pile friction resistance. Though controversy exists in the balance point, broken pile and jack combination, the self-balanced test serves as the best test method among the existing unfavourable test methods [16]. Professor Gong, W.M. [23, 24] has published self-balanced test related treatises and promoted the promulgation of self-balanced test for Chinese Ministry of Communications [25].

Meanwhile, the self-balanced test is conducted to vertical load for pile foundation of small diameter, large load and post-grouting. And the standards of China, America and Europe perform contrastive analysis to vertical bearing capacity. The test and analysis are implemented against the backdrop of such special background that few studies have been carried so far.

\section{POST-GROUTING TEST}

The Li-yuTuo bridge focuses on trial pile construction at early stage, including post-grouting test and selfbalanced test. This would take around 4 months to complete. The trial pile $3 \mathrm{c} 2$ was poured with underwater concrete on November 13, 2011, pile foundation underwent ultrasonic integrity test on November 21, 2011, and grouting was conducted to pile base and pile side on November 23, 2011. The trial pile 3c4 was poured with underwater concrete on November 14, 2011, pile foundation underwent NDT on November 21, 2011, and grouting was conducted to pile base and pile side on December 22, 2011. It was allowed to perform grouting only after pile foundation concrete attains over 80 percent of design strength. See Fig. 2 for grouting pipe embedded around pile foundation of $3 \mathrm{c} 2$. See Tab. 1 for grouting effect.

Table $1 \mathrm{~A}$ list of Post-grouting of $3 \mathrm{c} 2$ and $3 \mathrm{c} 4$

\begin{tabular}{|c|c|c|c|c|c|c|c|}
\hline \multirow{2}{*}{ Pile No. } & \multicolumn{3}{|c|}{ Actual dry cement mass / } & \multicolumn{2}{c|}{ Design dry cement mass / $\mathrm{t}$} & \multirow{2}{*}{$\begin{array}{c}\text { The percentage of actual grouting on } \\
\text { design grouting / \% }\end{array}$} \\
\cline { 2 - 7 } & Surround & Bottom & Total & Surround & Bottom & Total & $20 \%$ \\
\hline 3c2 & 0 & 1.4 & 1.4 & 3 & 4 & 7 & $28.6 \%$ \\
\hline $3 \mathrm{c} 4$ & 0.8 & 1.2 & 2 & 3 & 4 & 7 & \\
\hline
\end{tabular}

Use cement mass (dry cement) to signify grouting volume. It is suggested to adopt the ordinary Portland cement P.O 23.5 with water-cement ratio 0.55-0.65. When it comes to design, the grouting pipe should be concurrently used as ultrasonic detection tube. The 3 grouting pipes are embedded into bottom of pile with grouting volume of $4 \mathrm{~T}$ dry cement, ensuring that grouting pressure is no less than $4 \mathrm{MPa}$. The three grouting pipes along pile should be grouted with $1 \mathrm{t}$ dry cement with grouting pressure no less than $2 \mathrm{MPa}$. In construction site, $3 \mathrm{c} 2$ pile base is grouted with $1.4 \mathrm{t}$ cement, making sure the grouting is stopped when pile top emits cement grout. It is difficult to grout pile side on the following day. The grouting totals $1.4 \mathrm{t}$ which accounts for 20 percent of 
design grouting volume. The $3 \mathrm{c} 4$ pile bottom is grouted with $1.2 \mathrm{t}$ cement, ensuring that grouting is terminated when pile top emits cement grout. On the next day the pile side is grouted with $0.8 \mathrm{t}$ cement slurry, making certain grouting stops when pile top emits cement grout. The grouting totals $2 \mathrm{t}$ which accounts for 28.6 percent of design grouting volume. The actual grouting volume is far lower than design grouting volume. This may be attributed to two factors: one is the contractor lacking grouting technology and the other is design grouting volume overestimate. According to standard [26], the grouting volume should be calculated per Eq. (1) in consideration of the factors such as pile diameter, pile length, pile tip, soil property at pile side and the growing rate of single-pile bearing capacity. The main strata covered in the project are sand gravel. Obtain value from the largest grouting coefficient 3.8 as per Tab. 2, the largest grouting volume $3.8 \times 1.2=4.6 \mathrm{t}$. The designed volume $7 \mathrm{t}$ is obviously an overestimate.

$G_{C}=\alpha_{p} d$

where $G_{C}$ refers to grouting volume of single pile, namely dry cement mass, t. $\alpha_{p}$ is grouting coefficient, see Tab. 2. $d$ is the pile diameter.

\begin{tabular}{|c|c|c|c|c|c|c|c|c|c|}
\hline \multicolumn{1}{|c|}{ Table 2 A list of Post-grouting of 3c2 and 3c4 } \\
\begin{tabular}{|c|c|c|c|c|c|c|c|}
\hline Bearing straum & Clay/silty soil & Silt & Fine sand & Medium sand & Gravel soil & Rough sand & Gravel \\
\hline Value range & $2.1 \sim 2.5$ & $2.5 \sim 3.2$ & $2.4 \sim 2.7$ & $2.3 \sim 2.7$ & $2.3 \sim 2.8$ & $3.1 \sim 3.8$ & $3.1 \sim 3.8$ \\
\hline
\end{tabular}
\end{tabular}

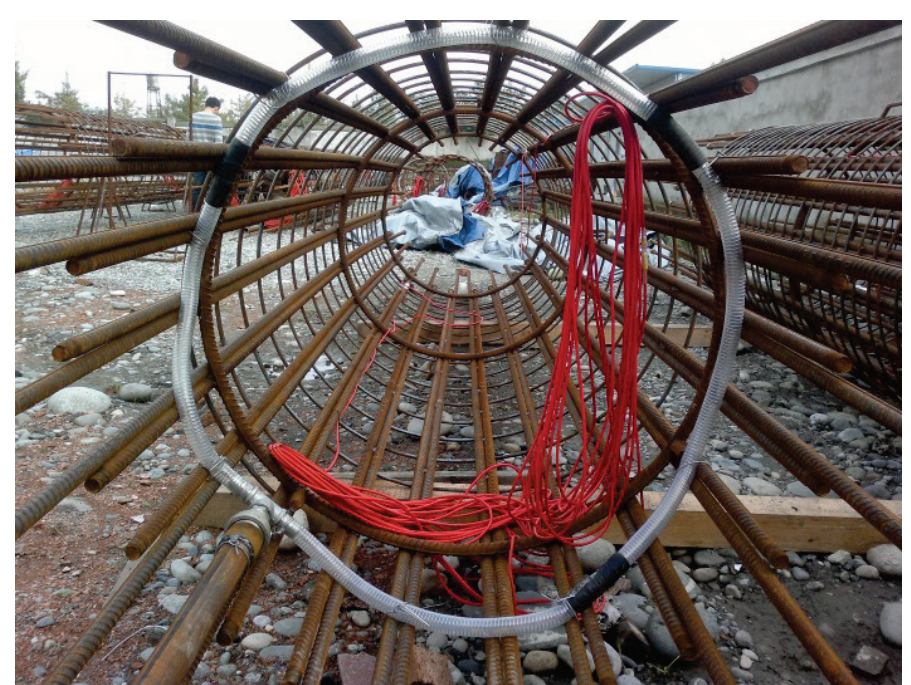

Figure 2 The embedded grouting pipe around pile foundation of $3 c 2$

\section{POST-GROUTING TEST}

\subsection{An Overview of Trial Pile Foundation}

The design drawing [27] displays that the trial pile is selected at bridge axis, serving as the load-bearing working pile as well. It lies in the east river bank of Jinmariver. Under No.3 pier sits pile cap underneath which there are four single piles that are working piles $-3 \mathrm{c} 1,3 \mathrm{c} 2,3 \mathrm{c} 3$ and $3 \mathrm{c} 4$. The $3 \mathrm{c} 2$ and $3 \mathrm{c} 4$ piles are chosen as trial piles, with concrete grade being $\mathrm{C} 40$, diameter 1.2 meter and length 33 meters. The estimated vertical bearing capacity of single pile is $33000 \mathrm{kN}$. See Fig. 3 for plane graph of trail pile foundation.

As a kind of pile static load test, the self-balanced test is designed to place load box (integrated jack) in the balance point of pile and calculate vertical bearing capacity of single pile through test data. Embed the specially-made loading device - jack (namely load box) in the designated location of pile, and lead high pressure pile and displacement pipe of jack to the ground. The high-pressure oil pump fills oil and pressurizes jack on the ground, and then jack transfers force to pile, where the mechanical friction resistance of upper pile equilibrates the ultimate friction resistance and tip resistance of lower pile to maintain loading, thus obtaining pile bearing capacity [25]. Based on Newton acting force and counterforce, the selfbalanced test can easily measure ultimate bearing capacity of single pile using equilibrium principle of pile tip resistance and pile friction resistance, without relying on reaction force externally provided by pile-loading or anchor pile [28].

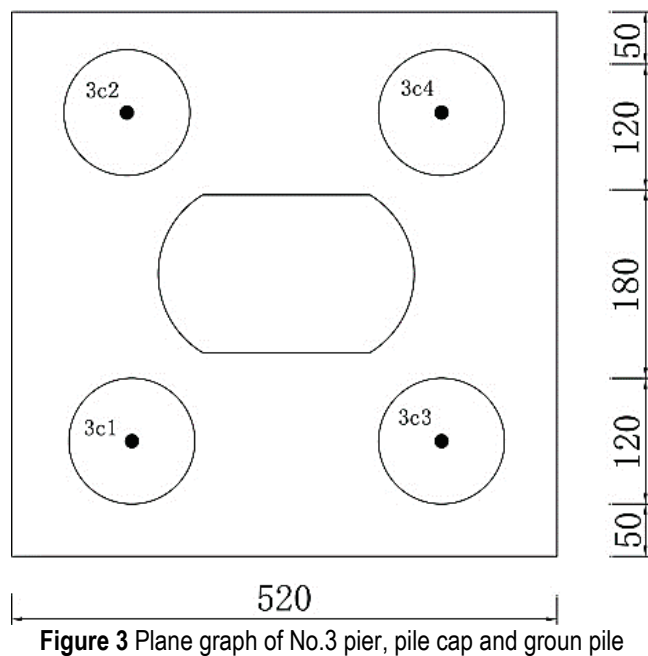

\subsection{Stratum Lithology}

The investigation report [29] reveals that the emerged and disclosed stratum is Quaternary holocene-series filling soil (Q4me) and Quaternary holocene-series river Qhapl 
$(\mathrm{Q} 4 \mathrm{al}+\mathrm{pl})$. The project uses bored piles, which takes erratic boulder or boulder layer as bearing stratum of pile tip, and regards friction as complex load-carrying pile foundation. See Fig. 4.

The geotechnical engineering character index, pile tip resistance and pile side resistance are presented in Tab. 3.

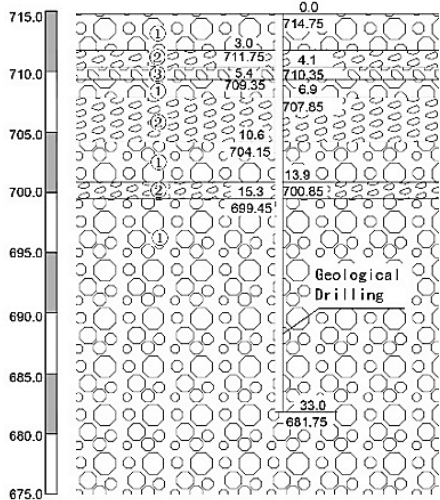

Figure 4 The geological profile of No.3 hole

Table 3. Measurement results

\begin{tabular}{|c|c|c|c|c|c|}
\hline Geotechnical name & $\begin{array}{l}\text { Gravity } \\
/ \mathrm{kN} / \mathrm{m}^{3}\end{array}$ & $\begin{array}{c}\text { Internal friction } \\
\text { angle } /{ }^{\circ}\end{array}$ & $\begin{array}{l}\text { Allowable bearing } \\
\text { capacity / } \mathrm{kPa}\end{array}$ & $\begin{array}{c}\text { Standard value of ultimate pile } \\
\text { side resistance / } \mathrm{kPa}\end{array}$ & $\begin{array}{c}\text { Standard value of ultimate pile tip } \\
\text { resistance / } \mathrm{kPa}\end{array}$ \\
\hline Fill soil & 17.5 & 1 & / & 1 & 1 \\
\hline Fine-grained sand & 18.5 & 20 & 110 & 40 & l \\
\hline Pebbles mixed with soil & 20.0 & 28 & 180 & 100 & l \\
\hline Pebbles & 20.5 & 35 & 320 & 140 & 1 \\
\hline Boulders mixed with soil & 21.0 & 40 & 550 & 200 & 3000 \\
\hline Boulders & 22.5 & 45 & 800 & 300 & 4000 \\
\hline
\end{tabular}

\subsection{Self-Balanced Test}

The $3 \mathrm{c} 2$ and $3 \mathrm{c} 4$ pile foundation share the same specification and model of jack and supporting pressure gage. Li-yuTuo bridge adopts five sets of YG220*2-330 integrated jacks, of which each jack features rated jacking force of $3300 \mathrm{kN}$ and a total of $16500 \mathrm{kN}$ for five sets of jack. The 5 sets of jack employs together with oil gage. The calibration result shows the pressure is virtually consistent with gage reading. See Fig. 5 for the calibration of oil gauge of No.01 jack. Refer to Fig. 6 for the picture of integrated jack. $3 \mathrm{c} 2$ and $3 \mathrm{c} 4$ pile foundations have undergone self-balanced test on January 9, 2012, with jack force loading level referring to Tab. 4.

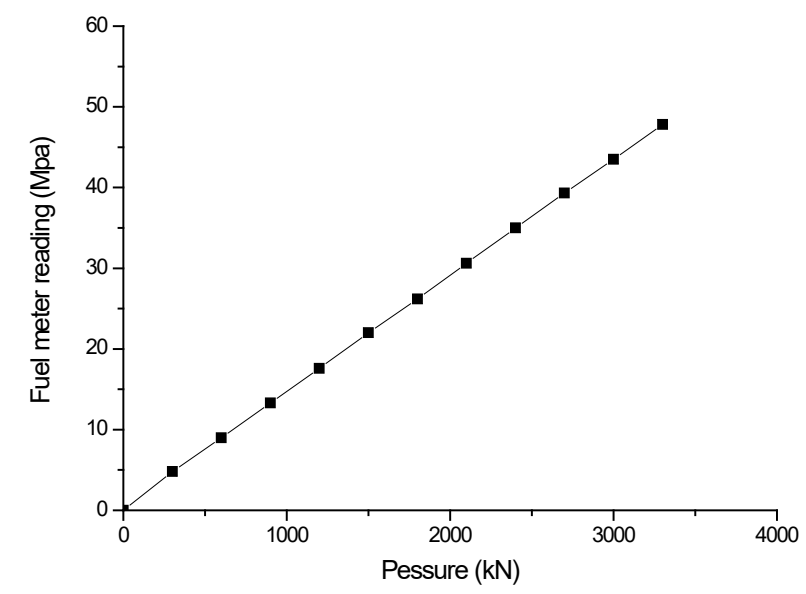

Figure 5 The direct proportion curve of calibration for No.01 jack of $3 \mathrm{c} 2$
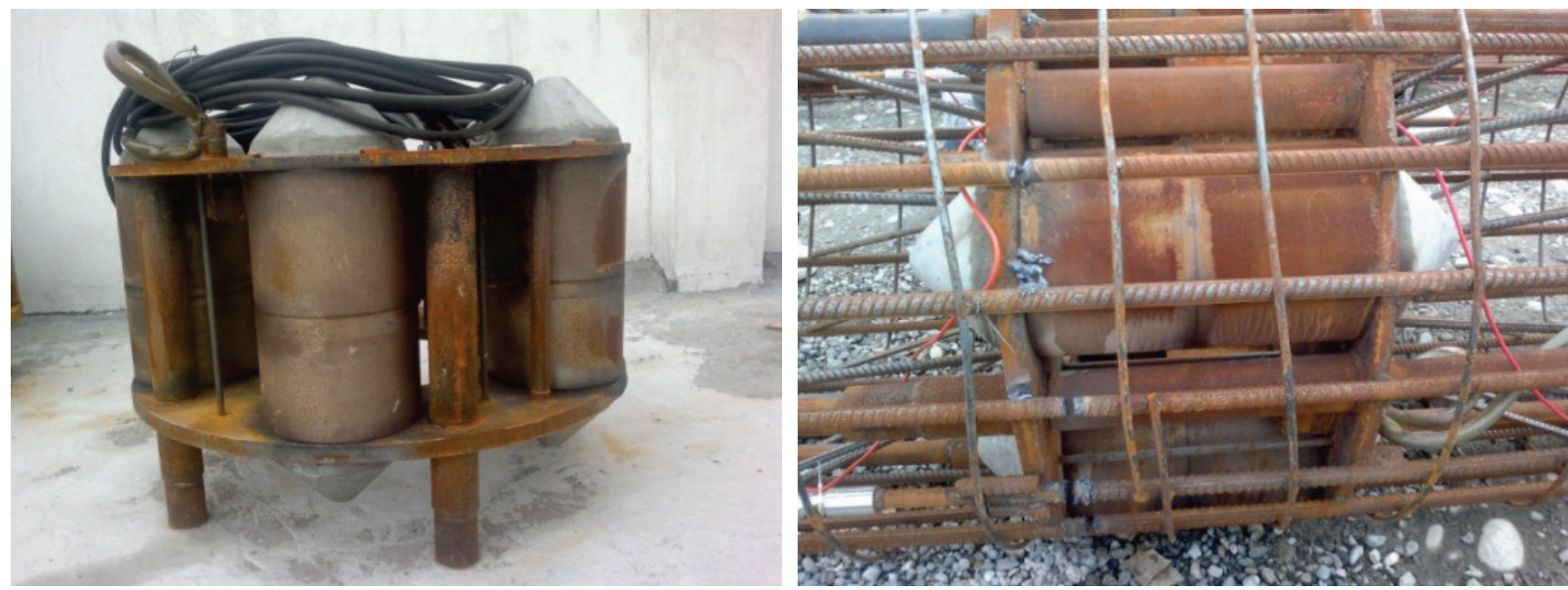

Figure 6 Picture of integrated jack

Table 4 A list of Post-grouting of $3 \mathrm{c} 2$ and $3 \mathrm{c} 4$

\begin{tabular}{|c|c|c|c|c|c|c|c|c|c|c|c|c|c|c|c|c|}
\hline $\begin{array}{c}\text { Load sequence } \\
\text { number }\end{array}$ & 1 & 2 & 3 & 4 & 5 & 6 & 6 & 8 & 9 & 10 & 11 & 12 & 13 & 14 & 15 & 16 \\
\hline $\begin{array}{l}\text { Jack force } \\
(1000 \mathrm{kN})\end{array}$ & 2 & 3 & 4 & 5 & 6 & 7 & 8 & 9 & 10 & 11 & 12 & 13 & 14 & 15 & 16 & 18 \\
\hline
\end{tabular}

Note: Due to jack reaction force and counterforce, the actual force value should be twice the value displayed in the following chart; e.g. standard value is 18 , the actual loading force value is $2 \times 18000 \mathrm{kN}$. 


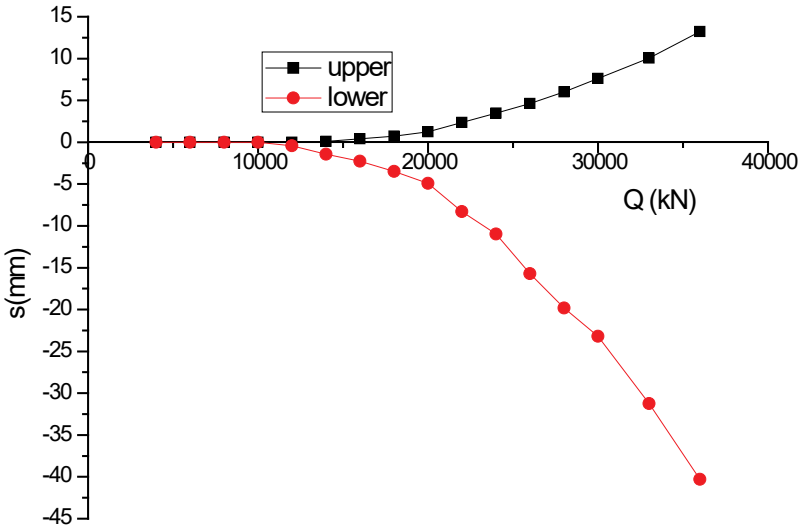

Figure 7 Q-s curve of pile foundation $3 c 2$

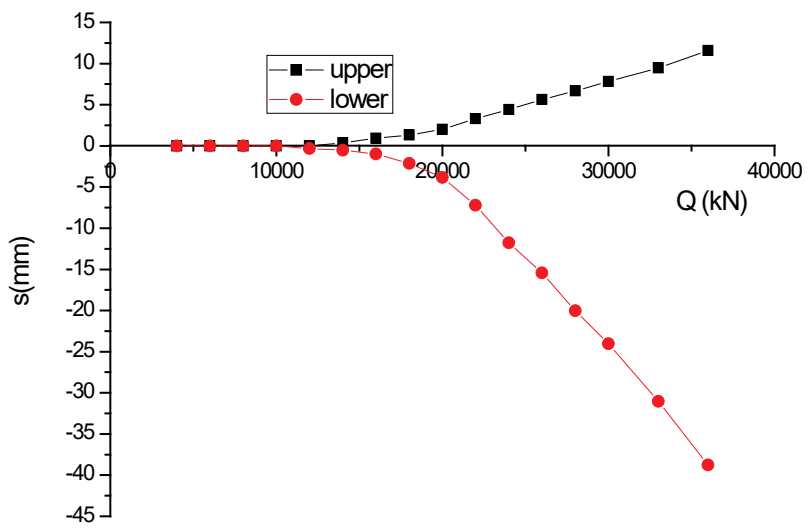

Figure 8 Q-s curve of pile foundation 3c4

When $3 \mathrm{c} 2$ trial pile is loaded to Level-16 (the corresponding load value is $2 \times 18000 \mathrm{kN}$ ), move upward by $13.22 \mathrm{~mm}$ and downward by $40.29 \mathrm{~mm}$. The pile top moves $6.31 \mathrm{~mm}$. As this has reached estimated load value, stop the loading activities and start to unload. For $3 \mathrm{c} 4$ trial pile, when it is loaded to Level-16 (the corresponding load value is $2 \times 18000 \mathrm{kN}$ ), move upward by $11.57 \mathrm{~mm}$ and downward by $38.75 \mathrm{~mm}$. The pile top moves $6.51 \mathrm{~mm}$. As this has reached estimated load value, stop the loading activities and start to unload. See Fig. 7 and Fig. 8 for the curve drawn from test result.

According to standard [25], the ultimate compressive resistance of single $3 \mathrm{c} 2$ and $3 \mathrm{c} 4$ pile is $39220 \mathrm{kN}$, which exceeds estimated value of $33000 \mathrm{kN}$.

$P_{u i}=\frac{Q_{u u i}-W_{i}}{\lambda_{i}}+Q_{l u i}$

Where $P_{u i}$ refers to ultimate bearing capacity value of trial pile $i(\mathrm{kN}), Q_{u u i}$ refers to ultimate loading value of upper pile $i$, obtaining $18000 \mathrm{kN}, Q_{l u i}$ refers to ultimate loading value of lower pile $i$, obtaining $18000 \mathrm{kN}, W_{i}$ refers to self-weight of upper pile of load box for pile $i$, obtaining $10204 \mathrm{kN}, \lambda_{i}$ refers to correction coefficient of trial pile $i$ which is determined based on the soil type at upper load box, the project uses 0.8 .

\section{COMPARISON OF BEARING CAPACITY OF PILE FOUNDATION AMONG CHINESE, AMERICAN AND EUROPEAN STANDARD}

4.1 The Calculation Formula Used by Three Countries for Bearing Capacity of Pile Foundations

The Chinese standard [30] is calculated per Eq. (3),

$R_{a}=\frac{1}{2} u \sum_{i=1}^{n} \beta_{s i} q_{i k} l_{i}+\beta_{p} A_{p} q_{r}$

It adds side resistance and tip resistance coefficient on the basis of single-pile bearing capacity formula. Where:

$R_{a}$ - admissible value of single-axial resistance of pile tip post-grouting / $\mathrm{kN}$

$u$ - pile length of each soil layer / $\mathrm{m}$

$\beta_{s i}$ - side resistance reinforced coefficient after grouting (see Tab. 4)

$\beta_{s i}-1.0$ when grouting is not performed

$q_{i k}$ - friction resistance standard value of soil and pile side $/ \mathrm{kPa}$

$l_{i}$ - the thickness of each soil layer under local scour / $\mathrm{m}$ $\beta_{p}$ - reinforced coefficient of tip resistance (see Tab. 5)

$\beta_{p}-1.0$ when grouting is not performed

$A p$ - cross section area of pile tip $/ \mathrm{m}^{2}$

$q r$ - admissible bearing capacity of soil at pile tip / $\mathrm{kPa}$

The American standard [26] is calculated per following Eq. (4).

The factored resistance of drilled shafts, $R_{R}$, shall be taken as:

$R_{R}=\varphi_{q p} R_{p}+\varphi_{q s} R_{s}$

where:

$R_{R}$ - resistance of drilled shafts

$\varphi_{q p}$ - resistance factor for tip resistance

$R_{p}$ - nominal shaft tip resistance

$\varphi_{q s}$ - resistance factor for shaft side resistance

$R_{s}$ - nominal shaft side resistance

Eurocode [31] is calculated per Eq. (5)

$R_{c ; k}=R_{b ; k}+R_{s ; k}=A_{b} q_{b ; k}+\sum_{i} A_{s ; i} \cdot q_{s ; i ; k}$

The characteristic compressive resistance of the ground, $R_{c ; k}$, may be derived from the characteristic values of the base resistance, $R_{b ; k}$ and of the shaft resistance, $R_{s ; k}$, crossection area of the base, $q_{s ; i ; k}$. The design resistance, $R_{c ; d}$, shall be derived from or: $R_{c ; d}=R_{b ; k} / \gamma_{b}+R_{s ; k} / \gamma_{s}$. 


\begin{tabular}{|c|c|c|c|c|c|c|c|}
\hline \multicolumn{1}{|c|}{ Table 5 A list of Post-grouting of 3c2 and 3c4 } \\
\begin{tabular}{|c|c|c|c|c|c|c|c|}
\hline Soil & Clay/silt & Sand & Fine sand & Medium sand & Rough sand & Gravel & Gravel soil \\
\hline$\beta_{s i}$ & $1.3 \sim 1.4$ & $1.5 \sim 1.6$ & $1.5 \sim 1.7$ & $1.6 \sim 1.8$ & $1.5 \sim 1.8$ & $1.6 \sim 2.0$ & $1.5 \sim 1.6$ \\
\hline$\beta_{p}$ & $1.5 \sim 1.8$ & $1.8 \sim 2.0$ & $1.8 \sim 2.1$ & $2.0 \sim 2.3$ & $2.2 \sim 2.4$ & $2.2 \sim 2.4$ & $2.2 \sim 2.5$ \\
\hline
\end{tabular}
\end{tabular}

$A b$ stands for the admissible bearing capacity of pile soil, qbik stands for pile side area, $A_{s, i}$ stands for friction resistance standard value of each soil and pile side.

\subsection{The Bearing Capacity of Pile Foundation Calculated by Three Countries}

The calculation result is shown in Tab. 6 based on Eqs. (3), (4) and (5).

Without considering grouting, the calculation value of bearing capacity covered in Chinese and American standard is similar to each other, while the value indicated in European standard is much greater, which is 34.7 percent greater than Chinese standard and 42.9 percent greater than American standard. This implies Chinese and American standard are extremely conservative. The formulas used by three countries are virtually identical, where the bearing capacity of pile foundation includes side resistance and tip resistance. The side resistance is associated with rock and soil at pile side and side area. The tip resistance is related to rock and soil at pile tip and bottom area. What three standard formulas differ from one another is that the side resistance in Chinese standard encompasses coefficient $1 / 2$ however this is not reflected in American and European standard. In American standard exists another coefficient which varies based on rock and soil. Meanwhile, European standard employs the coefficient reciprocal $\frac{1}{\gamma_{b}}$ and $\frac{1}{\gamma_{b}}$.

From the perspective of post-grouting, the Chinese standard specifies the reinforced coefficient of postgrouting for pile foundation strength, and endows growth coefficient and side resistance coefficient for pile side and pile tip. Tab. 6 shows that the theoretical bearing capacity of pile foundation increases by 78.8 percent after grouting in sand pebble.

Table 6 The Sheet of Theoretical Value Calculation for Bearing Capacity

\begin{tabular}{|c|c|c|c|c|c|c|c|}
\hline \multirow[b]{2}{*}{ Nationality } & \multicolumn{3}{|c|}{ Shaft tip } & \multicolumn{3}{|c|}{ Shaft side } & \multirow{2}{*}{$\begin{array}{c}\text { Resistance of } \\
\text { single drilled } \\
\text { shafts / kn }\end{array}$} \\
\hline & $\begin{array}{l}\text { Resistance factor } \\
\text { for tip resistance }\end{array}$ & $\beta_{s}$ & $\begin{array}{l}\text { Nominal shaft tip } \\
\text { resistance / kn }\end{array}$ & $\begin{array}{l}\text { Resistance factor for } \\
\text { shaft side resistance }\end{array}$ & $\beta_{s}$ & $\begin{array}{l}\text { Nominal shaft side } \\
\text { resistance / kn }\end{array}$ & \\
\hline $\mathrm{CHN}$ & 1.0 & & 4522 & 0.5 & & 17100 & 21622 \\
\hline CHN post-grouting & 1.0 & 2.5 & 11304 & 0.5 & 1.6 & 27361 & 38665 \\
\hline U.S. & 0.5 & & 2261 & 0.53 & & 18126 & 20387 \\
\hline EUP & 0.8 & & 3617 & 0.77 & & 26308 & 29925 \\
\hline
\end{tabular}

Note: The symbol used by each country is different, but the meaning is almost the same. The pile bottom area: $\frac{\pi d^{2}}{4}=\frac{\pi \times 1.2^{2}}{4}=1.13 \mathrm{~m}^{2}$. The standard value

of ultimate tip resistance of pile at boulder is $4000 \mathrm{kPa}$. The standard value of thickness and ultimate side resistance for pebble, boulder mixed with soil and boulder is $1.3 \mathrm{~m}, 6.2 \mathrm{~m}, 25.5 \mathrm{~m}$ and $140 \mathrm{kPa}, 200 \mathrm{kPa}$ and $300 \mathrm{kPa}$ respectively. See Fig.4. The resistance reinforced coefficient for post-grouting of pile side and pile tip covered in Chinese standard [30] is $\beta_{s}=2.5$ and $\beta_{s}=1.6$. The value of the partial factors in the European standard is the interval value $\left(\gamma_{b}=1.0 \sim 1.6, \gamma_{s}=1.0 \sim 1.3\right)$. If European standard uses smaller coefficient, the bearing capacity value calculated would be on an increase. The maximum value adopted here is $\gamma_{b}=1.6$ and $\gamma_{s}=1.3$. The Tab. 5 shows $\frac{1}{\gamma}=\frac{1}{1.6}=0.625, \frac{1}{\gamma}=\frac{1}{1.3}=0.7$.

\subsection{Comparative Analysis on Bearing Capacity}

See Tab. 7 for theoretical value of bearing capacity

The two trial piles are considered as working piles. They share the same geological condition, loading condition and termination condition and the static load test result of $39220 \mathrm{kN}$, which meets the requirement of 33000
$\mathrm{kN}$. Due to poor grouting effect, it is difficult to ensure the bearing capacity of each pile because of grouting difference and instability. The design bearing capacity has not been optimized according to test result, so the pile bearing capacity still uses the estimated capacity of 33000 $\mathrm{kN}$.

Table 7 A list of bearing capacity comparison

\begin{tabular}{|c|c|c|c|c|c|c|}
\hline \multirow{4}{*}{ Trial pile } & \multicolumn{6}{|c|}{ Ultimate bearing capacity of pile foundation / $\mathrm{kN}$} \\
\hline & \multirow{3}{*}{ Design value } & \multirow{3}{*}{$\begin{array}{l}\text { Static load test } \\
\text { value }\end{array}$} & \multicolumn{4}{|c|}{ Theoretical value used by three countries } \\
\hline & & & \multicolumn{2}{|c|}{ China } & \multirow{2}{*}{ America } & \multirow{2}{*}{ Europe } \\
\hline & & & Ordinary & Post-grouting & & \\
\hline $3 c 2 / 3 c 4$ & 33000 & 39220 & 21622 & 38665 & 20387 & 29925 \\
\hline
\end{tabular}

Though post-grouting effect has not achieved designed target - the $3 \mathrm{c} 2$ and $3 \mathrm{c} 4$ actual grouting volume accounts for 20 percent and 28.6 percent of design volume, the postgrouting can greatly increase vertical bearing capacity of pile foundation. The formula indicated in Chinese standard [30] shows that the bearing capacity before and after grouting is $21622 \mathrm{kN}$ and $38655 \mathrm{kN}$ respectively. This indicates bearing capacity is increased by 78.8 percent after grouting comparing with that before.
The American standard [26] mentioned the fact that post grouting can also affect shaft resistance. And Eurocode [32] mentioned that post-grouting, shaft and/or base grouting shall be carried out to cast-in-place bored piles only after the concrete has set. However American [26] and European standard [31, 33] possess no pile foundation strength or strength growth coefficient. They have not jointly formulated the formula to obtain the strength of bored pile after grouting; instead their attention 
is paid to the static load test whose result is used to optimize design.

Though Chinese standard [25] has unified the strength growth coefficient after bored pile grouting (see Tab. 4) and formulated relevant bearing capacity formula (see Eq. (3)), China is a country with a vast territory, where each area differs in geological and hydrologic condition, even the different location in same area could vary a little bit and the stratum of different depth in same location could be also different. Therefore, the writer believes Eq. (3) is a formula that is only recommended or suggested to be used rather than being compulsorily used. For bored piles and post-grouting for pile foundation, the writer hereby puts forward two suggestions: 1: prepare bearing capacity formula for different areas across China; it is suggested to use bearing capacity of different areas instead of the national bearing capacity Eq. (3). This allows bearing capacity formula to be more specific and practical. 2: As large bridge and super-large bridge involve many pile foundations, it is proposed to follow the concept of "test first, design second and construction third" and to optimize design based on test result obtained from post-grouting test and static load test. Abandon the traditional practice "design first, test second and construction third", where the large coefficient is adopted and test is only for the purpose of verifying design. This has not truly fulfilled design optimization, which is neither scientific nor cost effective.

It can be inferred from Tab. 6 that trial value is 18.8 percent greater than design value, 81.4 percent greater than Chinese standard value before grouting, and 1.44 percent greater than Chinese standard value after grouting. The trial value is highly consistent with Chinese standard value after grouting, demonstrating the designed vertical bearing capacity of single pile is feasible being $33000 \mathrm{kN}$.

\section{CONCLUSIONS}

The bearing capacity of $3 \mathrm{c} 2$ and $3 \mathrm{c} 4$ pile foundations is increased through post-grouting. The static load test uses self-balanced test. The three standard formulas are used to calculate bearing capacity and compare the test result with standard calculation result, with conclusion as follows:

(1) The design grouting volume is $7 \mathrm{t}$. The $3 \mathrm{c} 2$ actual grouting volume is $1.4 \mathrm{t}$ that accounts for 20 percent of design volume. $3 \mathrm{c} 4$ actual grouting volume is $2 \mathrm{t}$, accounting for 28.6 percent of design volume. The actual grouting volume falls far short of design requirement. Thus great efforts are required to study and test grouting effect and rules.

(2) The design value of bearing capacity is $33000 \mathrm{kN}$ and test value is $39330 \mathrm{kN}$, of which the latter is $6220 \mathrm{kN}$ greater than the former, exceeding by 18.8 percent.

(3) The bearing capacity covered in the Chinese standard normally is $21622 \mathrm{kN}$. Such value would increase to $38665 \mathrm{kN}$ after grouting, which is $17043 \mathrm{kN}$ more than pile foundation not being grouted and witnesses an increase of 78.8 percent. This shows bearing capacity enjoys a remarkable increase after grouting.

(4) For ordinary pile foundations, the calculation values indicated in Chinese and American standard are similar to each other, nevertheless European standard is much greater. The Chinese and American standards turn to be excessively conservative.
(5) Chinese standard specifies grouting amount and strength growth coefficient. However these are not available in American and European standard.

The unique design and test of pile foundation provides an important reference for similar projects.

\section{Acknowledgements}

This study is supported by the National Natural Science Foundation (Grant Nos. 51508358, 4167020785, 41502242); Towns and Villages Disaster Prevention and Mitigation Engineering Research Center of Sichuan Colleges and Universities funded projects (Grant No. CDPMV1403); and Research and Innovation Teams funded projects of Sichuan Provincial Department of Education (Grant No. 16TD0006).

\section{REFERENCES}

[1] The construction drawing of Li-yu Tuo main bridge in Jinmahe, Dujiangyan city, Sichuan province. Chengdu Engineering Corporation Limited, HYDROCHINA, 2011.

[2] The design drawing of trial pile for Li-yuTuo bridge in Jinmahe, Dujiangyan city, Sichuan province. Chengdu Engineering Corporation Limited, HYDROCHINA, 2011.

[3] Luo, Q. X. (2003). Pile foundation Test Manual. China Communications Press.

[4] Gong, W. M., Dai, G. L., \& Huang, S. G. (2009). Postgrouting technology for bored pile of large deep-water bridge. China Communications Press.

[5] Fleming, W. G. K. (1993). The Improvement of Pile Performance By Base Grouting. Civil Engineering, 97, 8893. https://doi.org/10.1680/icien.1993.23262v

[6] Cheng, Y., Gong, W. M., Zhang, X. G., \& Dai, G. L. (2010). Experimental Research on post grouting under super-load and large-diameter bored pile tip. Chinese Journal of Rock Mechanics and Engineering, 29, 3885-3892.

[7] Wan, Z. H., Dai, G. L., Gong, W. M., Chen, H. J., \& Chen, X. Y. (2017). Analysis on the load transfer function of postgrouting bored pile based on self-balanced method. China Civil Engineering Journal, 50, 98-104.

[8] Bauer, J., Pula, W., \& Wyjadlowski, M. (2018). Pile Load Test Results as a Basis for Reliability Calculation with Parabolic Response Surface. Tehnicki Vjesnik-Technical Gazette, 25, 558-564. https://doi.org/10.17559/TV-20150124002223

[9] Zhou, R. X., Gong, W. M., \& Mu, T. F. (2011). Test Research on Bearing Capacity Character of Post-Grouting piles for taiping bridge. Industrial Construction, 41, 422-427.

[10] Huang, T., Gong, W. M., \& Dai, G. L. (2011). Research on Base Grouting Effects of Piles in SURAMADUStrait Area of Indonesia. Chinese Journal of Rock Mechanics and Engineering, 30, 3269-3274.

[11] Dapp, S. \& Dan, B. (2010). Evaluation of Base Grouted Drilled Shafts at the Audubon Bridge. Proceedings of the GeoFlorida 2010 Conference on Advances in Analysis, Modeling and Design, 1553-1562. https://doi.org/10.1061/41095(365)157

[12] Lai, P., Mcvay, M., Bloomquist, D., \& Forbes, H. (2010). An Innovative Prefabricated Pile Installation Method Utilizing Jetting and Pressure Grouting. Proceedings of the GeoFlorida 2010 Conference on Advances in Analysis, Modeling and Design, 1592-1601. https://doi.org/10.1061/41095(365)161

[13] Su, S. F. (2009). Anisotropic strength evaluation of clay reinforced with grout piles. Journal of Geotechnical \& Geoenvironmental Engineering, 135, 1529-1537. https://doi.org/10.1061/(ASCE)GT.1943-5606.0000091 
[14] Mullins, G. \& Winters, G. (2006). Predicting End Bearing Capacity of Post-Grouted Drilled Shaft in Cohesionless Soils Journal of Geotechnical \& Geoenvironmental Engineering, 132, 478-487. https://doi.org/10.1061/(ASCE)1090-0241(2006)132:4(478)

[15] Ruiz, M. E. (2006). Study of axially loaded post grouted drilled shafts using cpt based load transfer curves. Masters Abstracts International, 44, 1440.

[16] Huang, X. B., Hou, S., Pu, H., \& Wang, C. L. (2015). Current situation analysis on vertical bearing capacity of pile foundation measured by self-balanced test. Building Structure, 45, 79-84.

[17] Shi, P. D. (1998). Further discussion on Osterberg static load test performed to trial pile. Industrial building, 02, 56-58.

[18] Shi, P. D. \& Lu, Y. (1999). Theosterberg load test method for drilled shafts and driven piles the first ten years. Industrial building, 29, 17-18.

[19] Gong, W. M., Guo, Z. X., \& Jiang, Y. S. (1998). The application of Osterberg trial pile in China. Building construction, 03, 31-32.

[20] Gong, W. M., Dai, G. L., \& Xue, G. Y. (2004). Study on selfbalanced test performed to super-long bored pile of Donghai bridge. Mineral exploration, 02, 40-43.

[21] Dai, G. L., Gong, W. M., Wang, L., \& Zhu, W. B. (2017). Application of self-balanced test pile method in steel composite pile foundation of port wharf. China Harbour Engineering, 10, 37-41.

[22] Gong, C. Z., He, C. L., \& Gong, W. M. (2012). Analysis of size effect on large diameter rock-socketed pile based on self-balance method. Rock and Soil Mechanics, 33, 24032407.

[23] Gong, W. M. \& Dai, G. L. (2016). The study and application of self-balanced test performed to pile bearing capacity. China Architecture \& Building Press.

[24] Gong, W. M. \& Dai, G. L. (2006). The study and application of self-balanced test performed to pile bearing capacity. China Architecture \& Building Press.

[25] JT/T 738-2009: Static loading test of foundation pile-Self balanced method. Beijing, China communications Press, 2009.

[26] AASHTO 2012: Standard Specifications for Highway Bridges, $6^{\text {th }}$ Edition. Washington, DC: American Association of State Highway and Transportation Officials, 2012.

[27] The design specification for construction drawing of Li-yu Tuo main bridge in Jinmahe, Dujiangyan city, Sichuan province. Chengdu Engineering Corporation Limited, HYDROCHINA, 2011.

[28] Huang, X. B., Wang, X. Y., Pu, H., \& Hou, S. (2015). Application of self-balanced test in Li-yu Tuo Bridge. Building Structure, 45, 87-91.

[29] The report on the investigation of geotechnical engineering for Li-yu Tuo bridge in Jinmahe, Dujiangyan city. Chengdu Engineering Corporation Limited, HYDROCHINA, 2010.

[30] JTG D63-2007: Code for Design of Ground Base and Foundation of Highway Bridges and Culverts. Beijing, China communications Press, 2001.

[31] BS EN 1997-1: Eurocod 7:Geotechnical design-Part 1: General rules. European Committee for Standardization. The authority of the Standards Policy and Strategy Committee, 2004.

[32] BN EN 1536: Execution of special geotechnical works Bored piles. European Committee for Standardization, 2010.

[33] BS EN 1997-1: Eurocod 7:Geotechnical Design - Part 2: Ground investigation and testing. European Committee for Standardization. The authority of the Standards Policy and Strategy Committee, 2007.

\section{Contact information:}

Xianbin HUANG, Associate Professor

(Corresponding author)

Civil Engineering, Sichuan Agricultural University,

Member of Sichuan Higher Education Engineering Research

Center for Disaster Prevention and Mitigation of Village

Construction,

Sichuan 611830, China

E-mail: hxianbin@sicau.edu.cn

Yujiao MEl, Master

Civil Engineering, Sichuan Agricultural University,

Member of Sichuan Higher Education Engineering Research

Center for Disaster Prevention and Mitigation of Village

Construction,

Sichuan 611830, China

E-mail: m13167980916@163.com

Yahong WANGREN, Student

Civil Engineering, Sichuan Agricultural University,

Sichuan 611830, China

E-mail: WRyahong@163.com

\section{Tangyong LI, Master}

Transportation bureau of xingwen county, yibin city,

sichuan province, 644000 , China

E-mail: 1428724458@163.com

Bo LEl, Master

Guang'an Vocational Technical College, Guangan,

Sichuan 638500, China

E-mail: 350906886@qq.com

Wei ZHAO, Master

Civil Engineering, Sichuan Agricultural University,

Member of Sichuan Higher Education Engineering Research

Center for Disaster Prevention and Mitigation of Village

Construction,

Sichuan 611830, China

E-mail:1353545072@qq.com 